\title{
Analysis of the relevance of the first year elementary school dynamization
}

\section{Análisis de la pertinencia de la dinamización educativa de primer año de primaria}

GARCÍA-ROJAS, Jesús Alberto*†, OROPEZA-MENDEZ, José Martín and RODRÍGUEZ-AGUILAR, Raquel

Instituto Tecnológico Superior del Occidente del Estado de Hidalgo, Ingeniería en Gestión Empresarial, Ingeniería en Tecnologías de la Información y Comunicaciones

ID $1^{\text {st }}$ Author: Jesús Alberto, García-Rojas / ORC ID: 0000-0002-0292-0789, Researcher ID Thomson: I-9224-2018

ID $1^{\text {st }}$ Coauthor: José Martín, Oropeza-Mendez

ID $2^{\text {nd }}$ Coauthor: Raquel, Rodríguez-Aguilar

\begin{abstract}
The objective of the present paper is to introduce dynamization through ICT on the subject of "knowledge of the environment" for the first year of basic education. Since it is currently handled through books and knowledge is not implemented through interactions, understanding the environment lies in precisely recognizing the elements that surround the student so that they can interact with it. If we show the students videos, animations and audios on how the environment is comprised, their academic growth can be more significant and be better inserted to its context. The methodology that was used was experimental, from which the prototype shown in this article was built, contributing to generate the tools that improve educational quality. The circulation of the article will be the missing step to have an impact on the elementary schools of Valle del Mezquital and Mexico, where projects like this are needed.
\end{abstract}

\section{ICT, Environment, Continuous Improvement}

\begin{abstract}
Resumen
El presente objetivo de investigación es la dar a conocer la dinamización mediante TIC de la materia de conocimiento del ambiente para el primer año de educación básica, ya que actualmente se maneja mediante libros y no se implementa un conocimiento donde el alumno pueda interactuar, el conocimiento del ambiente radica en precisamente conocer los elementos que rodean al alumno para que se vaya involucrando e interactuando con el mismo y si le mostramos por medio de videos, animaciones, audio como es que este se compone puede tener mayor significatividad su crecimiento académico y se inserte en mejor forma a su contexto. La metodología que se utilizó fue la experimental con la cual se fue construyendo el prototipo mostrado en este artículo, con lo cual se contribuye a generar las herramientas qué mejoren la calidad educativa, solo faltará la difusión del articulo para tener impacto en las primarias del Valle del Mezquital y de México, proyectos así hacen falta.
\end{abstract}

TIC, Ambiente, Mejora Continua

Citation: GARCÍA-ROJAS, Jesús Alberto, OROPEZA-MENDEZ, José Martín and RODRÍGUEZ-AGUILAR, Raquel. Analysis of the relevance of the first year elementary school dynamization. Journal Health, Education and Welfare. 2019. 34: $21-27$

\footnotetext{
* Correspondence to Author (email: jgarcia@itsoeh.edu.mx)

$\dagger$ Researcher contributing as first author
} 


\section{Introduction}

The environment is in constant change and innovation, which is why the educational field should not move away from that. The implementation of Information and Communication Technologies can achieve significant progress in the way students learn and teachers educate. The main idea is to innovate the way of imparting knowledge to elementary school children through an educational platform, where each student can have access to a device through which they receive information and/or knowledge in a fast, didactic and fun way, as well as serving as a starting point in the face of a technological world, so that children begin to know the use and implementation of technology and devices such as computers.

The objective of the educational platform is that students can, to some extent, control the time they take to learn a subject and if they do not understand a subject, they can solve it quickly with a single click, thanks to the fact that, aside from offering exercises to solve, the education platform can provide attractive tutorials or support tools to help and advise the students.

\section{State of the art}

New technologies have substantially changed the way in which we approach knowledge. Cell phones, tablets and computers connected to the internet opens the door to a world of information. There are more than 10 educational web platforms which elementary school children can use to learn; they are free and require an internet connection.

Mundo Primaria: This platform contains hundreds of games and resources to promote learning in subjects such as Mathematics, languages and knowledge of the environment.

Smartick: it offers the student numerical comprehension and explanation from an interactive point of view, making it all related to mathematical operations.

Childtopia: This platform specializes in online games and resources for children in primary and secondary education.

\section{Innovation description:}

IntelEdu's goal is that elementary students who are in marginalized areas of Mixquiahuala can access an education platform, through a WiFi connection without the use of the Internet, which allows them to learn and provide feedback to the topics taught in class.

\section{Benefits of innovation:}

It provides access of many technologies to children of primary level who do not have enough resources to access the internet.

- Safe and healthy content
$-\quad$ Low costs
- The contents of the platform are very
dynamic
The contents reinforce the knowledge
learned in class from a playful
perspective to encourage fun and
interaction

- The Raspberry's WiFi technology connects several computers, tablets and cell phones wirelessly.

\section{Methodology:}

In order to develop this research project, a comparative study analysis was used, in which we analyzed the various applications that exist in the education market for primary level. A documentary analysis was also conducted, where the evolution of education at a national level was reviewed. Finally, a documentary investigation of the context of Mixquiahuala was carried out in order to generate a research or software prototype, using spiral programming methodology.

\section{Potential market:}

Students: 12,824,766 elementary students registered in the Secretariat of Public Education.

\section{Target market:}

Elementary students from the three locations with the highest level of marginalization in Mixquiahuala (Monte Grande, El Colorado and El Tumba). 


\section{Competing technologies and competitors (substitute competition):}

There are three platforms that are widely used in primary schools, although there are more than 20 educational platforms on the Internet that elementary school children can use.

\begin{tabular}{|l|l|l|}
\hline \multicolumn{1}{|c|}{ Name } & \multicolumn{1}{c|}{ Description } & \multicolumn{1}{c|}{ Price } \\
Primaria & $\begin{array}{l}\text {-Offers educational games in the } \\
\text { different elementary subjects, in } \\
\text { all educational levels. } \\
\text {-Needs internet connection. } \\
\text {-Directed to children between 6 } \\
\text { and 12 years old. } \\
\text { It offers virtual games, children's } \\
\text { stories, }\end{array}$ & \\
\hline $\begin{array}{l}\text { Smarti } \\
\text { ck }\end{array}$ & $\begin{array}{l}\text {-Fully customized Online Math } \\
\text { Platform. } \\
\text { Develops a method to identify } \\
\text { strengths and } \\
\text { weaknesses of each child } \\
\text {-It has infinity of exercises to } \\
\text { solve. }\end{array}$ & \\
\hline Childtopia & $\begin{array}{l}\text {-Digital educational leisure space } \\
\text { for children, has a catalog of } \\
\text { constantly growing activities and } \\
\text { games. } \\
\text {-Needs Internet }\end{array}$ & \\
\hline
\end{tabular}

Table 1 Applications

\section{Intellectual Property Strategy:}

The protection of the IntelEdu image is essential, so we will rely on one of the legal figures offered by the IMPI; occupying a patent in order to maintain the identity of this product with its unique and distinctive characteristics within the country market. This patent will help us so that the commercial image is easily identified by the consumer, making unique its distinctive elements, such as the characteristics and cost that the card will have, also the feasibility of its use and operation.

The label and packaging will be protected so that it is not available for sale in other markets, affecting the image of the original product, and the most important point is ensuring the security of the information contained in IntelEdu; since it is an educational platform created for students of elementary level, it is our concern that this platform can be manipulated for misuse.

The requested patent will help us to ensure that the information offered cannot be plagiarized because names will be registered and protected by copyright, making it difficult to obtain data within this system.
Another benefit we have when obtaining the patent is that it assigns us exclusive use for 10 years and it can be renewable.

\section{Obstacles to enter the market:}

IntelEdu is an educational platform that will reach the hands of low-budget institutions which will help students have a complete education with more practical and dynamic activities that will allow them to develop a better understanding and learning of their subjects, leaving behind a system that does not improve their performance.

\begin{tabular}{|l|l|}
\hline $\begin{array}{l}\text { Strengths } \\
\text { Card price is very } \\
\text { accessible for } \\
\text { low-budget institutions }\end{array}$ & $\begin{array}{l}\text { Opportunities } \\
\text { Being a new favorable trend } \\
\text { in the educational market. } \\
\text {-To have the possibility of } \\
\text { establishing strategic } \\
\text { alliances to carry out } \\
\text { platforms at more } \\
\text {-Unique educational } \\
\text { platform } \\
\text {-Practical } \\
\text {-Dynamic } \\
\text {-It doesn't need Internet } \\
\text { to work }\end{array}$ \\
\hline $\begin{array}{l}\text { Weaknesses } \\
\text { We use government } \\
\text { support so that students } \\
\text { have the electronic } \\
\text { equipment for the card. } \\
\text { - That the advancement } \\
\begin{array}{l}\text { of technology affects } \\
\text { the platform's } \\
\text { operating system. }\end{array}\end{array}$ & $\begin{array}{l}\text { Threats } \\
\text { Entry of new competitors } \\
\text { other educational platforms. } \\
\text { have a lower price for } \\
\text { programming } \\
\text { platforms }\end{array}$ \\
\hline
\end{tabular}

Tabla 2 FODA

\section{Technical-economic pre-feasibility:}

\section{Suppliers}

- $\quad$ Suppliers must have relevant experience.

- Suppliers must comply with the deliveries granted on the corresponding dates.

- Suppliers must not exceed product budgets.

Suppliers must deliver quality materials to develop a premium product.

Suppliers will maintain a relationship of discretion to the company about product information.

- Suppliers must be aware of reimbursement insurance for product damage. 


\section{Manufacturers}

- Manufacturers must continue with the design order established by the company. Manufacturers must follow a certain budget established by the company.

- Manufacturers must prevent unskilled workers from participating in the production chain.

- Manufacturers must have a base of skilled workers to solidly support the product.

- Manufacturers must have supplier development tools that do not reach the required qualification.

- Manufacturers must avoid risks of brand deterioration due to avoidable failures.

The workers must make constant tests to avoid future failures in the creation of the product.

\section{Viabilidad financiera:}

\section{IMPI}

IntelEdu has requested financial support from IMPI. The support offered is to provide specialized and free advice so that we can be part of the patents, in order to provide tools for the protection of our inventions, use and export exclusively in accordance with the Mexican legal framework. Among the services that this program offers are patentability analysis, which consists of a study of the state of the art and technique, as well as advice regarding the writing of the application, free of charge. Within the program, workshops have been considered to disseminate the culture of intellectual property, the relevance of the protection and commercialization of developed inventions, including topics on competitive, commercial, technology and environmental monitoring.

\section{Secretariat of Public Education}

Support was requested for low-budget schools to have computer equipment so that these cards can be installed and children can adapt to a new fun and dynamic way of learning, making their development faster and their learning better. Also they will be more connected to the technology and facilities offered, helping them to try new things.

\section{Interview with experts:}

For the initiative of this project we had the support of Dr. Jesús Alberto García Rojas, who had the idea of creating a platform that could help students with limited resources to improve their way of learning in a simpler and more practical way, so that they no longer get frustrated with long textbooks and get involved with technology by showing them the benefits that it provides. Dr. Jesus teamed up with a professor at his institution, who showed him that this platform could be installed on a RASPBERRY card, it would not need the Internet, so as not to generate an expense to the institution, much less to parents.

- STUDENT: How will this project benefit students and how will it improve their learning?

-DR. JESUS: This card would benefit you in many ways, first you have to know that the card is made up of several ports that can be used to add memories that contain information of any kind, and apart from that, with a single card other teams can connect via Wifi. As a second important fact, students who do not have these services may be the first to try this way of learning.

\section{Analysis:}

Spanish is a subject aimed at the students' performance in a dynamic and physical way, making them obtain knowledge in person and in group dynamics, and because the beginning of the prototype cannot cover the amount of the number of students in a classroom (a complete group) is not viable.

The subject of Mathematics comprises dynamic learning. Since it is one of the most studied fields, there are more prototypes both computerized and digitally for smartphones, through games and applications; perhaps because it has been extensively explored, it could not be viable for starting the prototype. In the subject of Knowledge of the Environment, there could be an opportunity to start the prototype, since it has been neglected and it turns out to be dynamic to acquire knowledge by digital means; in addition, the block units turn out to have a sufficient amount of information, that is, not too short nor too extensive to be able to create the content. 
While in the Civics and Ethics subject, as well as with Knowledge of the Environment, has been little explored in digital knowledge and/or prototypes, its contents are somewhat extensive to start working at the moment.

\begin{tabular}{|c|c|}
\hline \multicolumn{2}{|r|}{ Knowledge of the environment } \\
\hline Start & $\begin{array}{ll}\text { 1. } & \text { Presentation } \\
\text { 2. } & \text { Know your book }\end{array}$ \\
\hline $\begin{array}{c}\text { Block } \\
1\end{array}$ & 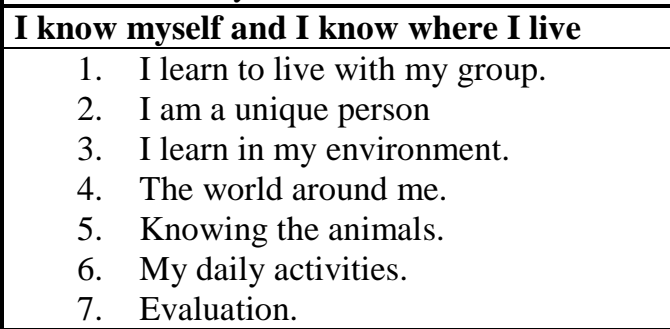 \\
\hline $\begin{array}{c}\text { Block } \\
2\end{array}$ & $\begin{array}{l}\text { I observe my changes and those of my } \\
\text { community } \\
\text { 1. I learn to live together in my school. } \\
\text { 2. I take care of my body and my diet. } \\
\text { 3. Light is important in my life. } \\
\text { 4. I take care of myself and the } \\
\text { environment where I live. } \\
\text { 5. The plants of my community. } \\
\text { 6. How do I change? } \\
\text { 7. Evaluation }\end{array}$ \\
\hline $\begin{array}{c}\text { Block } \\
\mathbf{3}\end{array}$ & $\begin{array}{l}\text { I experiment in my environment } \\
\text { 1. Agreements to live as a family. } \\
\text { 2. I know and take care of the place } \\
\text { where I live. } \\
\text { 3. How are objects? } \\
\text { 4. Change and movement. } \\
\text { 5. My family and I. } \\
\text { 6. Evaluation } \\
\end{array}$ \\
\hline End & $\begin{array}{ll}- & \text { Bibliography } \\
\text { - } & \text { Iconographic credits } \\
\text { - } & \text { Cut-out material }\end{array}$ \\
\hline
\end{tabular}

Tabla 3 Subject

Below is an example of Topic 5: Knowing the animals:

\section{Topic 5: Knowing the animals}

Objective: Generate curiosity and amazement when exploring the different types of animals and their characteristics, as well as raising awareness about how to care for animals.

Description: The theme is focused on presenting the domestic and non-domestic animals, and their characteristics, as well as knowing how to care for an animal.

Suggestion: Presenting a video about what are "wild" (non-domestic) and domestic animals.

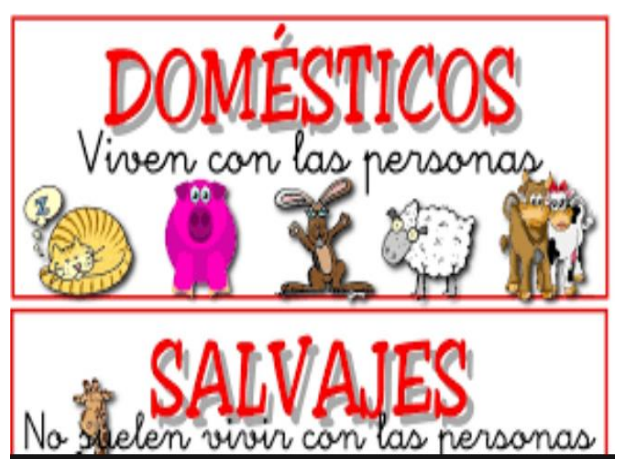

Figure 1 Animal screen

Presenting a video of several animals that mention their name and what sound they make.

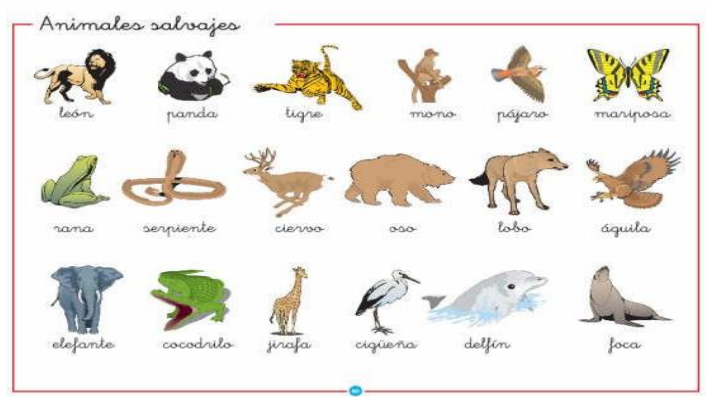

Figure 2 Multimedia

In the end, presenting all the animals in the video and sorting them into domestic or nondomestic with the mouse.

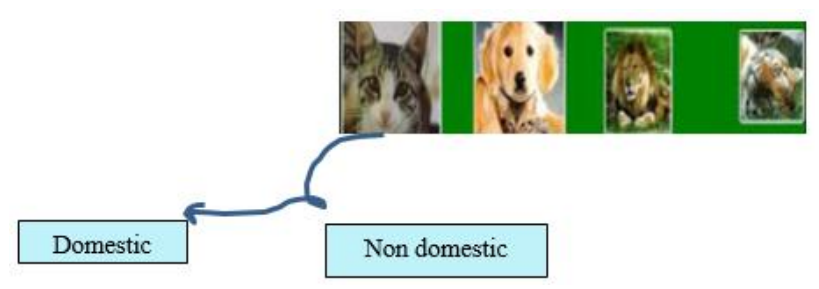

Figure 3 Animals

Sending a question that says: What is the difference between domestic and non-domestic animals? And answering it with the keyboard. Sending a video about how to care for animals.

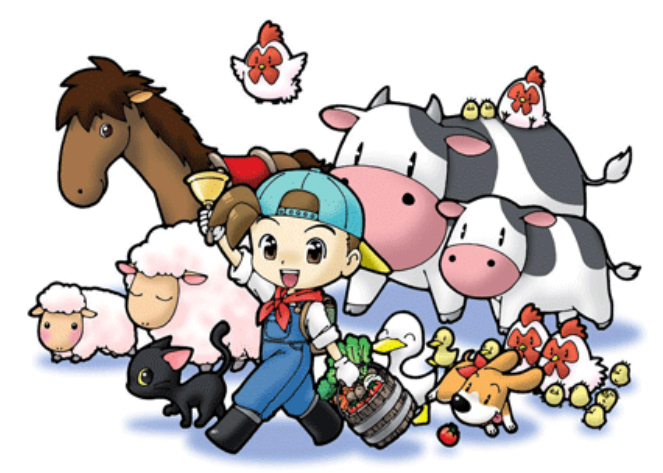

Figure 4 Animal care

GARCÍA-ROJAS, Jesús Alberto, OROPEZA-MENDEZ, José Martín and RODRÍGUEZ-AGUILAR, Raquel. Analysis of the relevance of the first year elementary school dynamization. Journal Health, Education and Welfare. 2019 
As an activity, they can make a drawing about what they learned on how to care for an animal.

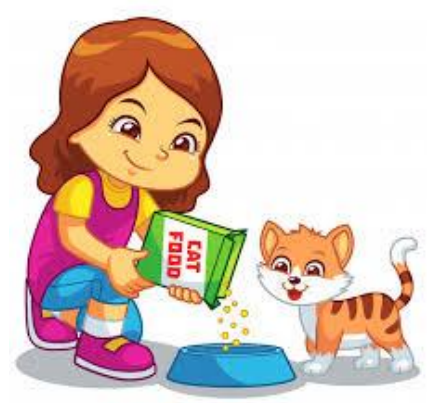

Figure 5 Animal care of animals.

Sending a video about the characteristics

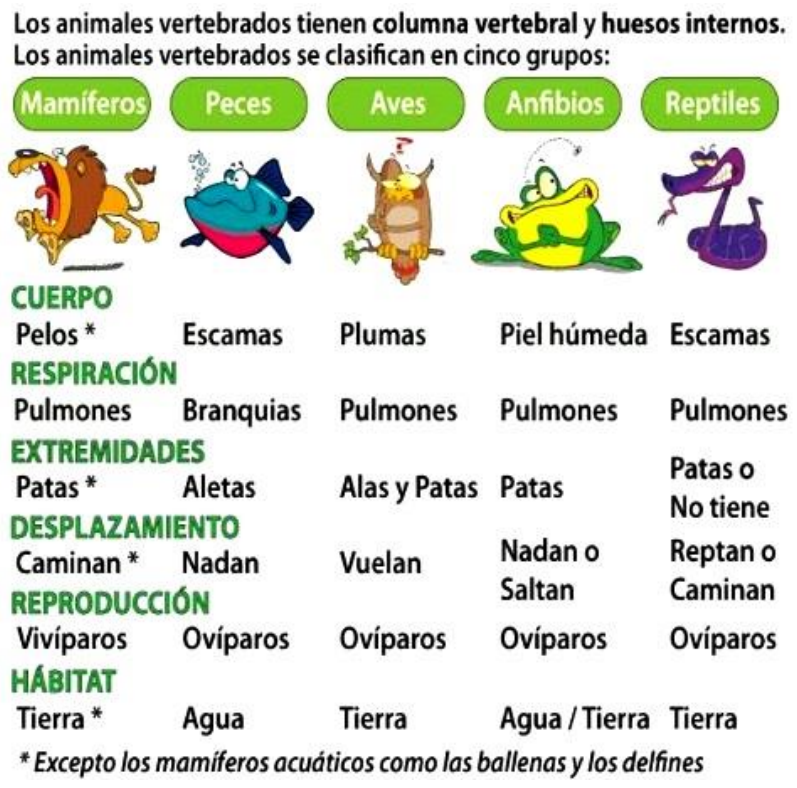

Figure 6 Animal characteristics

Placing 4 boxes on some characteristics so that they write 2 or 3 examples.

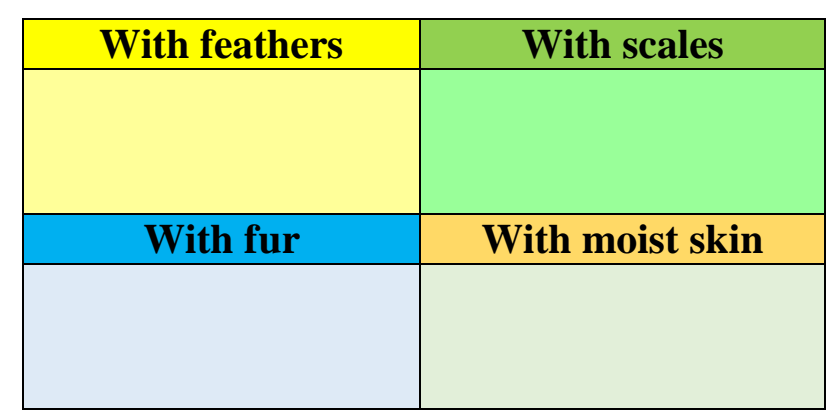

Table 4 Feature chart

\section{Learning:}

Identify that it is a domestic and non-domestic animal.
Know the sounds they produce.

Know what are the characteristics of animals.

\section{Índice}

\section{Presentación \\ Conoce tu libro}

\section{Bloque 1}

Me conozco y conozco el lugar donde vivo

Aprendo a convivir con mi
Soy una persona única
Me ubico en mi entorno
El mundo que me rodea
Conocemos a los animales
Mis actividades diarias
Evaluación

Figure 7 Table of Contents

\section{Conclusion}

Due to the interests of the prototype, it can be deduced that the subject of Knowledge of the Environment turns out to be more feasible, since there is not so much app development in this matter, and that the subjects are not so extensive or short to address them with the development of this application. It is worth mentioning that although the research methodology used to develop this project is not innovative, few studies exist worldwide addressing this problem, but the utility and impact that it has on society is even better, since this must be the goal of any investigation.

\section{Recommendations}

It is advisable to continue working on the link between technology and education, since there are many marginalized places in Mexico, which need modernization of technology, so that students develop digital skills that allow them to compete in the labor market. This low-cost project achieves it overcoming so many obstacles that do not allow the modernization of classrooms across the country. 


\section{References}

Aguaded Gómez, J. I., \& Tirado Morueta, R. (2008). Los centros TIC y sus repercusiones didácticas en primaria y secundaria en Andalucía. Educar, (41), 061-90.

Barrantes Casquero, G., Casas García, L. M., \& Luengo González, R. (2011). Obstáculos percibidos para la integración de las TIC por los profesores de Infantil y Primaria en Extremadura. Pixel-Bit. Revista de Medios y Educación, 39, 83-94.

Bordalba, M. M. (2016). La comunicación familia-escuela: el uso de las TIC en los centros de primaria. Revista electrónica interuniversitaria de formación del profesorado, 19(1), 73-83.

Domingo, M., \& Marqués, P. (2011). Aulas 2.0 y uso de las TIC en la práctica docente. Comunicar, 19(37), 169-175.

Espinosa, R. (15 de febrero de 2018). Matriz de análisis FODA. Obtained from DAFO: https://robertoespinosa.es/2013/07/29/1a-matrizde-análisis-dafo-foda/

García-Valcárcel, A., Basilotta, V., \& López, C. (2014). Las TIC en el aprendizaje colaborativo en el aula de Primaria y Secundaria. Comunicar, 21(42), 65-74.

gob.mx. (1 de mayo de 2019).gob.mx. Obtained from gob.mx: https://www.gob.mx/se/articulos/la-propiedad intelectual-industrial-en-mexico

Pérez, h. m. (3 de junio de 2008). Calidad y gestión. Obtained from calidad y gestión: http://calidad-

gestion.com.ar/boletín/72_evaluación_de_prove edores/

Rosas, A. ( 22 de MAYO de 2009). Estado de la técnica y sus distintos servicios: https://rosasalberto.es/2005/11/06/estadosdelast ecnicas-servicios/

Roblizo Colmenero, M. J., \& Cózar Gutiérrez, R. (2015). Usos y competencias en TIC en los futuros maestros de educación infantil y primaria: hacia una alfabetización tecnológica real para docentes. Píxel-Bit. Revista de Medios y Educación, 47, 23-39.
Roblizo Colmenero, M. J., \& Cózar Gutiérrez, R. (2015). Usos y competencias en TIC en los futuros maestros de educación infantil y primaria: hacia una alfabetización tecnológica real para docentes. Píxel-Bit. Revista de Medios y Educación, 47, 23-39.

Saez López, J. M. (2012). Valoración del impacto que tienen las TIC en educación primaria en los procesos de aprendizaje y en los resultados a través de una triangulación de datos. Relatec.

Trigueros Cano, F. J., Sánchez Ibáñez, R., \& Vera-Muñoz, M. I. (2012). El profesorado de Educación Primaria ante las TIC: realidad y retos.

Vértiz-Osores, R. I., Pérez-Saavedra, S., Faustino-Sánchez, M. A., Vértiz-Osores, J. J., \& Alain, L. (2019). Tecnología de la Información y Comunicación en estudiantes del nivel primario en el marco de la educación inclusiva en un Centro de Educación Básica Especial. Propósitos y Representaciones, 7(1), 83-94. 